\title{
Estrogen Receptor 1 Gene (ESR1) rs2234693 Polymorphism and Breast Cancer Risk in Saudi Women
}

\author{
Razan Jamaan Al-Amri', Mohammad Kdaimes H Alotibi', Rawya Ibrahim \\ AL-Raddadi', Weam Talal Yahya Shebli ${ }^{1}$, Emad Ibrahim Yagoub Fallatah ${ }^{2}$, \\ Ahmed Safar Alhujaily ${ }^{3}$, Hiba Salaheldin Mohamed ${ }^{1,4 *}$
}

\begin{abstract}
Objective: The present study aimed to determine the role of ESR1 gene rs2234693 T/C polymorphism (PvuII) in the susceptibility to breast cancer and to assess the association of this polymorphism within presence or absence of estrogen, progesterone receptors, human epidermal growth factor receptor 2 (HER2) and with premenopausal and postmenopausal age in Saudi women. Methods: The study was a retrospective case-control study. In this study, 137 breast cancer and 98 normal breast paraffin embedded tissues were included. DNA was extracted and ESR1 gene rs2234693 T/C polymorphism was genotyped by PCR-RFLP. Genetic association tests were performed. Results: The results showed no significant difference in distribution of rs $2234693 \mathrm{~T} / \mathrm{C}$ alleles and genotypes frequencies. Odd ratios $(95 \% \mathrm{CI})$ were $1.15(0.8-1.66)$ and 1.06 (0.5-1.98) and p values were 0.51 and 0.87 , respectively. The genotypes and alleles frequencies within different hormonal receptors groups and ages of menopause showed no signification association (odd ratios were less or close to 1 and p values $>0.05$ ). Conclusion: ESR 1 gene rs2234693 T/C polymorphism was not associated with susceptibility to breast cancer and different menopausal, hormone receptors, and HER2 status in breast cancer patients. Further analysis using larger sample size will be needed to assess the association of different polymorphisms within the gene and risk of breast cancer.
\end{abstract}

Keywords: Genetic variant- ESR1- breast cancer- Saudi Arabia

Asian Pac J Cancer Prev, 21 (11), 3235-3240

\section{Introduction}

Breast cancer $(\mathrm{BC})$ is a serious health issue, causing changes within the body cells and out of control cell grow (Alotaibi et al., 2018; Saggu et al., 2015). Saudi Cancer Registry (SCR) recorded a total of 6,922 female BC cases between January 2001 and December 2008. The number of female BC cases was $1,152,1,308$, and 1,473 in 2008, 2009, and 2010, respectively. In 2010, BC ranked first $(5,378$ cases, $27.4 \%)$ among females with newly diagnosed cancers (Saggu et al., 2015; Saudi Cancer Registry, 2005). In 2018, IARC reported BC as the most prevalent cancer in Saudi Arabia with 3629 new cases out of all other cancers among women (https://gco.iarc. fr/today/data/factsheets/populations/682-saudi-arabia-fa ct-sheets.pdf.).

Studies have shown that BC is a complex disease and factors such as gender, age, ethnicity, family history, genetic factors, menopausal status, radiation exposure, alcohol, and exposure to high dose of estrogen are associated with the risk of developing BC (Nindrea et al., 2017). Effects of estrogen are mediated through two distinct nuclear receptors, namely estrogen receptor alpha $(\mathrm{ER} \alpha)$ encoded by ESR 1 gene and estrogen receptor beta $(\mathrm{ER} \beta$ ) encoded by ESR2 gene (Deroo and Korach, 2006). Estrogen and its receptor ER1 have major function in development and progression of cancer. ER1 is an important mediators of hormonal response and a target for BC hormonal treatments (Debeb and Berihu, 2015). It also stimulates mammary epithelial tissue proliferation and differentiation through combining with estrogen (Clemons and Goss, 2001). ESR1 gene, located on chromosome 6q25.1, consists of eight exons and seven introns (Ponglikitmongkol et al.,1988). ESRl gene is a low-penetrance $\mathrm{BC}$ susceptibility gene. It may increase the likelihood of accumulation of genetic mutations occurring throughout cellular division. It functions as a ligand and stimulates cell proliferation and controls cell growth and cell death by binding to both endogenous and exogenous hormones. Genome-wide association studies have identified several single nucleotide polymorphisms (SNPs) within ESRl gene that are associated with predisposition 
to BC. ESR1 rs2234693 (PvuII) polymorphism is located in intron one and it is one of the most characterized SNPs of ESR1gene (Hill et al.,1989). It is also associated with increased risk of BC and other diseases in which estrogen is implicated (Deroo and Korach, 2006). Possible purposeful mechanism attributed to the present polymorphism includes a change in the expression of the ESR1 gene by altering the transcription factor binding sites and affecting alternative splicing of the ESR1 gene. However, the allele variant has been shown to be associated with $\mathrm{BC}$ risk in different populations (Chauhan et al., 2019). The present study aimed to find out the possible role of ESR 1 gene rs2234693 T/C polymorphism in the susceptibility to $\mathrm{BC}$. We also tried to evaluate the association of this polymorphism within presence or absence of estrogen, progesterone receptors, and human epidermal growth factor receptor 2 (HER2) and menopausal status.

\section{Materials and Methods}

\section{Study design and samples}

Breast tissue samples of Saudi women were collected from King's Fahad Hospital. All samples were archive, antonyms, and paraffin-embedded (FFPE)tissues. Clinical data of each patient was retrieved from King Fahad Hospital database. This hospital-based case-control study included 137 histopathological confirmed BC cases and 98 benign tissue samples as controls. The cases and controls were matched in age. Samples with different BC subtypes, including different receptors status ER, PR, HER2, and triple-negative (ER-, PR-, HER2-), were included.

\section{DNA extraction and genotyping}

The DNA was extracted from 5 to 8 pieces of $10 \mu \mathrm{m}$ thickness sections of paraffin embedded tissue. Through incorporation of several steps of heating and shaking, modified phenol-chloroform protocol method was used.

The primers were designed to amplify ESR 1 gene rs2234693 (T/C) polymorphism. Forward primer was 5, GGGTTATGTGGCAATGACGT 3', and reverse primer was 5' GACCAATGCTCATCCCAACTC 3' (Macrogen Company, South Korea) with an expected product size of $164 \mathrm{bp}$. The amplification was performed using T100 ${ }^{\mathrm{TM}}$
Thermal Cycler (Bio-Rad, Germany) instrument in a total volume of $25 \mu \mathrm{L}$ by Maxime PCR PreMix Kit (Intron biotechnology, South Korea). The PCR mix consisted of $2.5 \mathrm{mM}$ dNTPs, $5 \mathrm{U} / \mu 1 \mathrm{i}$-TaqTM polymerase, $1 \mathrm{X}$ reaction buffer, gel loading buffer, $1 \mu \mathrm{l}$ of $10 \mathrm{mM}$ of each primer, and $1 \mu \mathrm{l}$ of template DNA $(100 \mathrm{ng} / \mu \mathrm{l})$. PCR conditions consisted of 35 cycles following a hot start at $95^{\circ} \mathrm{C}$ for 3 minutes. Each cycle included the following three steps: DNA denaturation $\left(30\right.$ second at $\left.94^{\circ} \mathrm{C}\right)$, primer annealing $\left(30\right.$ second at $62^{\circ} \mathrm{C}$ ), and primer extension $(1$ minute at $72^{\circ} \mathrm{C}$ ). There was a final extension cycle for 5 minutes at $72^{\circ} \mathrm{C}$. The size of the amplified product was determined using $1 \%$ agarose gel electrophoresis. The amplified PCR product was digested by the PvuII enzyme (Thermo Fisher Scientific, USA). The DNA fragments were separated using 3\% low melting agarose gel. Restriction digestion by PvuII produced two fragments of 108 and 56bp.

\section{Sequencing}

Six samples were selected from three different genotypes (Homozygous wild type T/T, Heterozygous $\mathrm{T} / \mathrm{C}$, and Homozygous mutant $\mathrm{C} / \mathrm{C}$ ). PCR was performed in volume of $50 \mu 1$ and sent to Macrogen (Korea) company for sequence analysis, using same forward and reverse primers, to confirm RFLP genotype results.

\section{Genetic statistical analysis}

Allele and genotype frequencies of PvuII polymorphism of the genotypes were calculated. Deviation from Hardy Weinberg equilibrium was tested. Genetic association tests were performed using AssociatORRR software (https://www.genecalculators.net/associatorrr-cc.html). Odd ratio (OR) with $95 \%$ confidence intervals (CI) was used to express association. P-value $<0.05$ was considered statistically significant.

\section{Results}

Demographic information and clinicopathological features of of $B C$ patients

The average age of our patients was $51.2 \pm 14$ and $59(43.1 \%)$ ones aged $<50$ and $70(51.1 \%)$ aged $\geq 50$. Invasive-infiltrating ductal carcinoma was the most

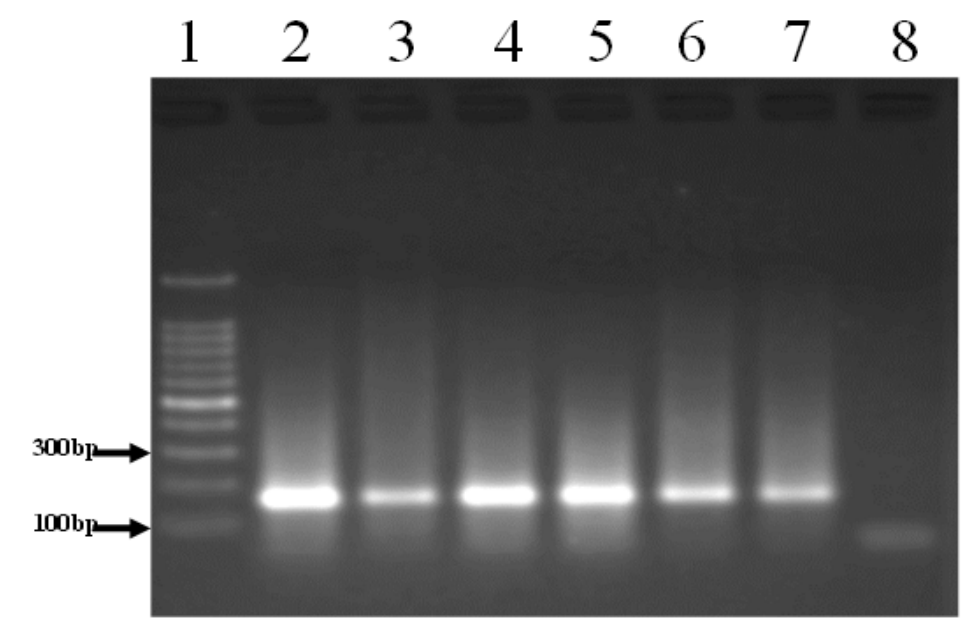

Figure 1. Representatives gel for PCR product. Lane 1, represents 100bp DNA molecular weight marker; Lane 2 to 7, PCR product (164bp); Lane 8, negative control. 


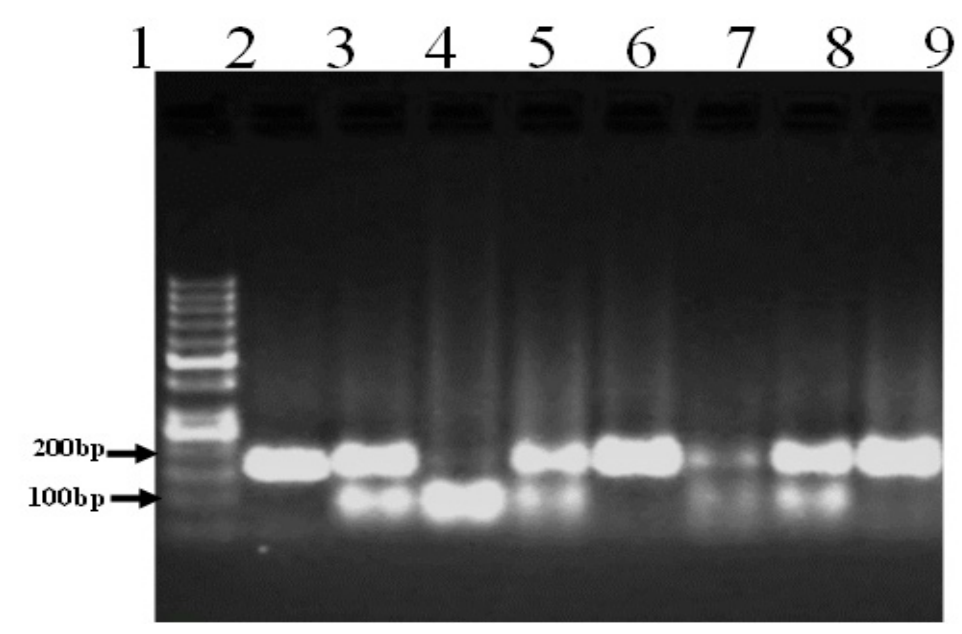

Figure 2. Representative gel for Ggenotyping of ESR 1 Gene Polymorphism. Lane 1, Represents 50bp DNA molecular weight marker; Lane 2, PCR product undigested (164bp); Lane 3 ,5, 7 and 8, Heterozygous T/C (164,108,56 bp). Lanes 6 and 9: Homozygous mutant C/C (164bp); Lane 4, Homozygous wild type T/T (108,56 bp).

Table 1. Genotype Frequencies of ESR1 Gene rs2234693T/C Polymorphism in Breast Cancer Patients versus Controls

\begin{tabular}{lcccc}
\hline Allele/Genotype & Cases (frequency) $\mathrm{n}=137$ & Controls (frequency) $\mathrm{n}=98$ & OR $(95 \% \mathrm{Cl})$ & $\mathrm{P}^{*}$ value \\
\hline $\mathrm{T}$ & $133(0.49)$ & $102(0.52)$ & $1.15(0.8-1.66)$ & 0.51 \\
$\mathrm{C}$ & $141(0.51)$ & $94(0.48)$ & & \\
$\mathrm{T} / \mathrm{T}$ & $33(0.24)$ & $26(0.27)$ & $1.06(0.56-1.98)$ & 0.87 \\
$\mathrm{~T} / \mathrm{C}$ & $67(0.49)$ & $50(0.51)$ & & \\
$\mathrm{C} / \mathrm{C}$ & $37(0.27)$ & $22(0.22)$ & & \\
\hline
\end{tabular}

ESR1, Estrogen receptor1 gene; OR, odd ratio (OR $\leq 1$ or close to 1 means the SNP does not affect odds of disease outcome); $\mathrm{Cl}$, Confidence interval; $\mathrm{n}$, Total number of samples; $\mathrm{P} *$ value, 2 tailed P value- Fisher's Exact Test. Cut off $\leq 0.05$

frequent histological subtype in our patients $(78.1 \%)$. Most of the patients were diagnosed at advanced clinical grades of II and III, $40.9 \%$ and $40.1 \%$, respectively. The results on hormone receptor status showed that $74(54 \%)$ out of 119 patients were ER-positive, 60 (43.8\%) were PR-positive, and 38 (27.7\%) were HER2-positive. Molecular subtyping using surrogate immunohistochemistry (IHC) markers showed that

\section{0}

T GTC CCAG CC GT T T TAT

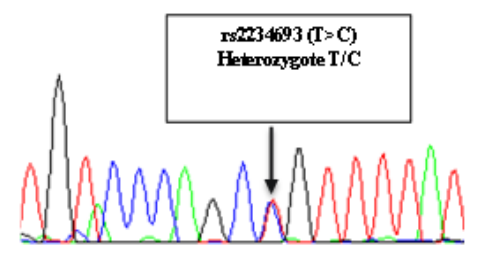

luminal A subtype predominated in patients (43.8\%), followed by HER2-like (15.3\%), and luminal B (12.4\%), while triple-negative subtype was represented in $13.9 \%$ of the patients.

\section{RCR-RFLP}

The PCR product for ESR1 gene rs2234693 T/C polymorphism generated size band of 164bp (Figure
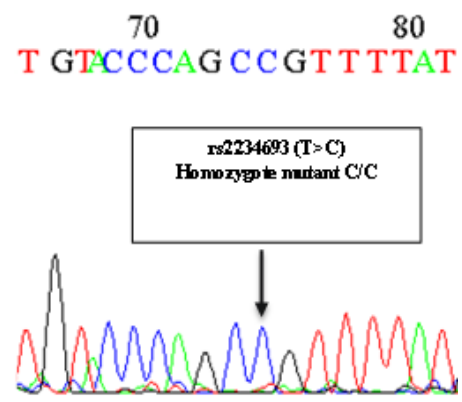

80

T G TACCCAG C TG T T T TAT

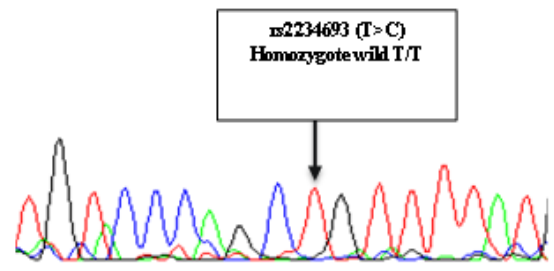

Figure 3. Electropherogram of Three Different Genotypes 
Table 2. Polymorphism of ESR1 PvuII and Breast Cancer Risk by a Menopausal Status and Receptors Statues

\begin{tabular}{|c|c|c|c|c|c|c|}
\hline Genotype/allele & $\begin{array}{l}\text { Controls (frequency) } \\
\qquad \mathrm{n}=98\end{array}$ & $\begin{array}{c}\mathrm{ER}+\text { cases } \\
\mathrm{n}=74\end{array}$ & $\begin{array}{c}\text { ER- cases } \\
\quad \mathrm{n}=45\end{array}$ & $\begin{array}{c}\text { Controls vs. ER+ } \\
\text { OR }(95 \% \mathrm{CI}) \\
\mathrm{P}^{*} \text { value }\end{array}$ & \multicolumn{2}{|c|}{ Controls vs. ER- OR $(95 \% \mathrm{CI}) \mathrm{P}^{*}$ value } \\
\hline $\mathrm{T}$ & $102(0.52)$ & $79(0.53)$ & $44(0.49)$ & $0.95(0.62 \sim 1.45)$ & \multicolumn{2}{|c|}{$1.13(0.69 \sim 1.87)$} \\
\hline $\mathrm{C}$ & $94(0.48)$ & $69(0.47)$ & $46(0.51)$ & $\mathrm{p}=0.83$ & \multicolumn{2}{|c|}{$\mathrm{p}=0.7$} \\
\hline TT & $26(0.27)$ & $22(0.3)$ & $10(0.22)$ & $0.83(0.41-1.7)$ & \multicolumn{2}{|c|}{$1.25(0.52-3)$} \\
\hline $\mathrm{TC}$ & $50(0.51)$ & $35(0.47)$ & $24(0.53)$ & $\mathrm{p}=0.87$ & \multicolumn{2}{|c|}{$\mathrm{p}=0.67$} \\
\hline $\mathrm{CC}$ & $22(0.22)$ & $17(0.23)$ & $11(0.24)$ & & & \\
\hline Genotype/allele & $\begin{array}{l}\text { Controls (frequency) } \\
\quad \mathrm{n}=98\end{array}$ & $\begin{array}{c}\mathrm{PR}+\text { Cases } \\
\mathrm{n}=60\end{array}$ & $\begin{array}{c}\mathrm{PR}-\text { cases } \\
\mathrm{n}=58\end{array}$ & $\begin{array}{c}\text { Controls vs. PR+ } \\
\text { OR }(95 \% \mathrm{CI}) \\
\mathrm{P}^{*} \text { value }\end{array}$ & \multicolumn{2}{|c|}{$\begin{array}{c}\text { Controls vs. } \mathrm{PR}-\mathrm{OR}(95 \% \mathrm{CI}) \\
\mathrm{P}^{*} \text { value }\end{array}$} \\
\hline $\mathrm{T}$ & $102(0.52)$ & $66(0.55)$ & $56(0.48)$ & $0.89(0.56 \sim 1.40)$ & \multicolumn{2}{|c|}{$1.16(0.73 \sim 1.84)$} \\
\hline $\mathrm{C}$ & $94(0.48)$ & $54(0.45)$ & $60(0.52)$ & $\mathrm{p}=0.64$ & \multicolumn{2}{|c|}{$\mathrm{p}=0.56$} \\
\hline TT & $26(0.27)$ & $20(0.33)$ & $12(0.20)$ & $0.68(0.32-1.43)$ & \multicolumn{2}{|c|}{$1.39(0.61-3.1)$} \\
\hline $\mathrm{TC}$ & $50(0.51)$ & $26(0.43)$ & $32(0.55)$ & $\mathrm{p}=0.34$ & \multicolumn{2}{|c|}{$\mathrm{p}=0.54$} \\
\hline $\mathrm{CC}$ & $22(0.22)$ & $14(0.23)$ & $14(0.24)$ & & & \\
\hline Genotype/allele & $\begin{array}{c}\text { Controls (frequency) } \\
\mathrm{N}=98\end{array}$ & $\begin{array}{c}\text { HER }+ \text { cases } \\
n=38\end{array}$ & $\begin{array}{c}\text { HER- cases } \\
\mathrm{n}=80\end{array}$ & $\begin{array}{c}\text { Controls vs. HER }+ \\
\text { OR }(95 \% \mathrm{CI}) \\
\text { P* value }\end{array}$ & \multicolumn{2}{|c|}{ Controls vs. HER- OR $(95 \% \mathrm{CI}) \mathrm{P}^{*}$ value } \\
\hline $\mathrm{T}$ & $102(0.52)$ & $38(0.50)$ & $84(0.53)$ & $1.09(0.64 \sim 1.84)$ & \multicolumn{2}{|c|}{$0.98(0.65 \sim 1.49)$} \\
\hline $\mathrm{C}$ & $94(0.48)$ & $38(0.50)$ & $76(0.48)$ & $\mathrm{p}=0.79$ & \multicolumn{2}{|c|}{$\mathrm{p}=1$} \\
\hline TT & $26(0.27)$ & $11(0.29)$ & $21(0.26)$ & $0.67(0.31-1.86)$ & \multicolumn{2}{|c|}{$1.04(0.51-2.1)$} \\
\hline $\mathrm{TC}$ & $50(0.51)$ & $16(0.42)$ & $42(0.53)$ & $\mathrm{p}=0.64$ & \multicolumn{2}{|c|}{$\mathrm{p}=1$} \\
\hline $\mathrm{CC}$ & $22(0.22)$ & $11(0.29)$ & $17(0.21)$ & & & \\
\hline Genotype/allele & \multicolumn{2}{|c|}{ Controls (frequency) $\mathrm{n}=98$} & \multicolumn{2}{|c|}{ TNBC cases $n=19$} & \multicolumn{2}{|c|}{ Controls vs. TNBC OR $(95 \% \mathrm{CI}) \mathrm{P}^{*}$ value } \\
\hline $\mathrm{T}$ & \multicolumn{2}{|c|}{$102(0.52)$} & \multicolumn{2}{|c|}{$18(0.47)$} & \multicolumn{2}{|c|}{$1.21(0.60 \sim 2.42)$} \\
\hline $\mathrm{C}$ & \multicolumn{2}{|c|}{$94(0.48)$} & \multicolumn{2}{|c|}{$20(0.53)$} & \multicolumn{2}{|c|}{$\mathrm{p}=0.72$} \\
\hline TT & \multicolumn{2}{|c|}{$26(0.27)$} & \multicolumn{2}{|c|}{$3(0.16)$} & \multicolumn{2}{|c|}{$2.08(0.54-8.03)$} \\
\hline $\mathrm{TC}$ & \multicolumn{2}{|l|}{$50(0.51)$} & \multicolumn{2}{|c|}{$12(0.63)$} & \multicolumn{2}{|c|}{$\mathrm{p}=0.37$} \\
\hline $\mathrm{CC}$ & \multicolumn{2}{|c|}{$22(0.22)$} & & $4(0.21$ & & \\
\hline Genotype/allele & $\begin{array}{c}\text { Pre controls } \\
\mathrm{n}=74\end{array}$ & $\begin{array}{c}\text { Pre cases } \\
\mathrm{n}=59\end{array}$ & $\begin{array}{c}\text { Post } \\
\text { controls } \\
\mathrm{n}=15\end{array}$ & Post cases $n=71$ & $\begin{array}{c}\text { Controls vs. Pre OR } \\
(95 \% \mathrm{CI}) \\
\mathrm{P} * \text { value }\end{array}$ & $\begin{array}{c}\text { Controls vs. Post } \\
\text { OR }(95 \% \mathrm{CI}) \\
\mathrm{P}^{*} \text { value }\end{array}$ \\
\hline $\mathrm{T}$ & $79(0.53)$ & $55(0.47)$ & $14(0.47)$ & $73(0.51)$ & $1.31(0.81 \sim 2.13)$ & $0.83(0.38 \sim 1.82)$ \\
\hline $\mathrm{C}$ & $69(0.47)$ & $63(0.53)$ & $16(0.53)$ & $69(0.49)$ & $\mathrm{p}=0.32$ & $\mathrm{p}=0.69$ \\
\hline TT & $21(0.28)$ & $13(0.22)$ & $3(0.20)$ & $19(0.27)$ & $1.27(0.54-2.05)$ & $0.69(0.16-2.91)$ \\
\hline $\mathrm{TC}$ & $37(0.50)$ & $29(0.49)$ & $8(0.53)$ & $35(0.49)$ & $\mathrm{p}=0.68$ & $\mathrm{p}=0.74$ \\
\hline $\mathrm{CC}$ & $16(0.21)$ & $17(0.29)$ & $4(0.27)$ & $17(0.24)$ & & \\
\hline
\end{tabular}

ESR1, Estrogen receptor1 gen; ER, Estrogen receptor; PR, Progesterone receptor; HER2, Human epidermal receptor 2 (HER2); TNBC,Triple negative breast cancer; Pre, Premenopausal; Post, Postmenopausal; N, number of samples; OR, odd ratio. (OR $\leq 1$ or close to 1 means the SNP does not affect odds of disease outcome); CI, confidence interval; P* value, 2 tailed P value- Fisher's Exact Test. Cut off $\leq 0.05$

1). Genotyping using the PvuII enzyme showed three different patterns (Figure 2).

\section{Sequencing}

The sequencing results obtained from Macrogen (Korea) company confirmed our results on different genotypes (Figure 3).

\section{Genetic statistical analysis}

The genetic analysis demonstrated similar distribution of PvuII polymorphism alleles and genotypes frequency between controls and cases (Table 1). The genotype frequencies revealed 0.24 of wild homozygous (TT), 0.49 of heterozygous (TC), and 0.27 of mutant homozygous (CC) in the cases. In the control group, the genotype frequencies were 0.27 of wild homozygous (TT), 0.51 of heterozygous (TC), and 0.22 of mutant homozygous (CC). The Minor allele frequencies were (C allele) 0.51 and 0.48 in cases and controls, respectively. There was no significant association between ESR1 gene rs2234693T > $\mathrm{C}$ polymorphism and susceptibility to $\mathrm{BC}$. Table 2 depicts a summary on the distribution of genotypes by menopausal status and hormonal receptor status. The results did not suggest any genetic association between menopausal status and predisposition to BC. No association was detected between ESR 1 gene rs 2234693 within presence or absence of the estrogen and progesterone hormones and HER2 in tumor samples (Table 2). The genotype and allele frequencies were in Hardy-Weinberg equilibrium where $\mathrm{p}$ values were $>0.05$. 


\section{Discussion}

$\mathrm{BC}$ is a multifactorial disease and it is not yet fully understood. GWAS has shown that the fundamental BC mechanisms are composed of genetic and environmental factors, and certain SNPs within susceptibility genes may have an impact on the development of BC (Albalawi et al., 2019). Numerous clinical studies have investigated SNPs within ESR1 gene while the most widely studied polymorphisms of ESR1 is rs2234693 (Abd Ellatif et al., 2016). This was the first study conducted in KSA investigating ESR1 gene PvuII polymorphism and BC. The changes in ESRl gene expression are possible functional mechanisms attributed to PvuII polymorphism (Anghel et al., 2010). It was reported that substitution of $\mathrm{T}$ by $\mathrm{C}$ led to loss of PvuII restriction site, and the resulted $\mathrm{C}$ allele produced myb transcription factor binding site, significantly increasing transcription compared to the T allele (Herrington et al., 2002). Several diseases, including BC (Zhang et al., 2015; Zhang et al., 2018), endometrial cancer (Ashton et al., 2009), prostate cancer (Li et al.,2017), Alzheimer's disease (Cheng et al., 2014), endometriosis and leiomyoma (Hsieh et al., 2007), and hepatocellular and gallbladder cancer (Sun et al., 2015) were assessed for probable association with PvuII polymorphism. In this study, no genetic association was found between PvuII polymorphism and BC risk. Similar results were shown in different populations, including Korean, Swedish, Americans, and Portugal (Shin et al., 2003; Sonestedt et al., 2009; Alves et al., 2010; Clendenen et al., 2013). The PvuII polymorphism of the ESR1 gene was associated with susceptibility to BC in different population such us Chinese, Indian, and Egyptian (Cai et al., 2003; Abd Ellatif et al., 2016; Chauhan et al., 2019). There are contrasting results in this regard. Some studies demonstrated that ESR1 gene PvuII polymorphism was significantly associated with the lower risk of BC in Asians but not in Caucasians populations ( Zhang et al., 2018). In a Meta-analysis, it was yielded that CC genotype was associated with an elevated risk of BC. However, TT or CT genotypes increased this risk in European and Caucasian (Hu et al., 2017). In different studies, PvuII 'C' allele was associated with high risk of $\mathrm{BC}$ in Asians, but with no risk in Euro-Americans population (Lu et al., 2013). This findings indicate that ethnicity and geographic location can contribute to the breast carcinogenesis (Zhang et al., 2015). The results of stratified analysis in this study did not reveal any genetic association between menopausal, hormonal, and growth receptors status and susceptibility to BC. Different studies indicated that menopausal status had an effect on estrogen production, cell signaling, and metabolism (Li and $\mathrm{Xu}, 2012$ ). Several meta-analysis studies indicated that the ESR1 PvuII polymorphism was associated with high risk of $\mathrm{BC}$ in pre-menopausal in comparison with post-menopausal women (Cai et al., 2003; González-Zuloeta Ladd et al., 2008). However, many studies (Shin et al., 2003; González-Mancha et al., 2008; Anghel et al., 2010), including this study, did not show any genetic associations between menopausal status and increased risk of $\mathrm{BC}$.

The PvuII polymorphism was associated with ER expression in BC patients (Hill et al., 1989). In another study, ER status was not associated with susceptibility to $\mathrm{BC}$, and PvuII $\mathrm{C}$ allele was found in high frequency in patients with PR negative (Anderson et al., 1994). This association was not found in the present study. Nevertheless, our results were in agreement with many studies in different populations, including Caucasian, Chinse, and Portugal populations ( Cai et al., 2003; Alves et al., 2010; Anghel et al., 2010).

In conclusion, these results indicated that ESR 1 $2234693 \mathrm{~T} / \mathrm{C}$ polymorphism was not associated with susceptibility to BC in Saudi women. It is likely that ethnic variation and environmental influences among different populations have an effect on association between SNPs and possible risk of BC. Further studies are needed to confirm this finding and assess the association of other polymorphisms within ESR1 gene with risk of BC .

\section{Ethic statement}

All study procedures were agreed by Taibah University, College of Dentistry Research Ethics Committee (TUCDREC/20170607), and from the Department Research Committee at King Fahd Hospital (ADCARE), Madinah

\section{Acknowledgements}

We are thankful to Departments of Histopathology and Oncology at King Fahad Hospital in Al-Madinah. Special thanks go to Mr. Mayyas Ali Jamal, a medical laboratory technician at Histopathology laboratory at King Fahad Hospital. This study was part of an approved thesis at Taibah University.

\section{Authors contribution}

HSM and MKHA contributed to conception and design of the study. RJA carried out the experimental work and assisted with data analysis. WTYS and RIA assisted with samples, data collection and DNA extraction. ASA and EIYF were the project clinicians facilitated acquisition of data. ASA conducted histopathological examination and provided samples. RJA and HSM prepared the manuscript. All authors read, commented on, and approved the final manuscript.

\section{Funding Statement}

No fund was received for this study

\section{Conflict of Interest}

The authors do not have any conflict of interest to declare.

\section{References}

Abd Ellatif M, Zahran MA, Denaiwar A, Elbaz A, Abdel Azeez HA (2016). Study of polymorphism of the estrogen receptor alpha gene as a genetic marker for the risk of breast cancer. IJCEBS, 4, 16-22.

Albalawi IA, Mir R, FM AD (2019). Utility of amplificationrefractory mutation system for the detection clinically significant estrogen and progesterone receptors gene 
variations in breast cancer patients in Saudi Arabia. IAJPS, 6, 4734-47.

Alotaibi RM, Rezk HR, Juliana CI, Guure C (2018). Breast cancer mortality in Saudi Arabia: modelling observed and unobserved factors. PLoS One, 13, e0206148.

Alves SM, Mesquita L, Sousa R, Peralta F, Silva HC (2010). Polymorphisms of estrogen receptors, ER $\alpha$ and GPR30: association with breast cancer susceptibility and prognosis. BMC Proc, 4, 6.

Anderson TI, Heimdal KR, Skrede M, et al (1994). Oestrogen receptor (ESR) polymorphisms and breast cancer susceptibility. Hum Genet, 94, 665-70.

Anghel A (2010). Estrogen receptor alpha polymorphisms: correlation with clinicopathological parameters in breast cancer. Neoplasma, 57, 306-15.

Ashton KA (2009). Estrogen receptor polymorphisms and the risk of endometrial cancer. An Int J Gynecol Obstet, 116, 1053-61.

Cai Q (2003). Genetic polymorphisms in the estrogen receptor $\alpha$ gene and risk of breast cancer: results from the Shanghai breast cancer study. Cancer Epidemiol Biomarkers Prev, 12, 853-9.

Chauhan P, Yadav R, Kaushal V, Kadian L (2019). Evaluation of genetic polymorphism in estrogen receptor $\alpha$ gene as breast cancer risk. Biomed Res, 30, 72-7.

Cheng D, Liang B, Hao Y, Zhou, W (2014). Estrogen receptor $\alpha$ gene polymorphisms and risk of Alzheimer's disease: evidence from a meta-analysis. Clin Interv Aging, 9, 1031-8.

Clemons M, Goss P (2001). Estrogen and the risk of breast cancer. N Engl J Med, 344, 276-85.

Clendenen T (2013). Genetic variants in hormone-related genes and risk of breast cancer. PLoS One, 8, e69367.

Debeb YG, Berihu BA (2015). Review on the role of estrogen receptors in breast cancer. Int J Pharm Sci Res, 6, 1100-4.

Deroo BJ, Korach KS. (2006). Estrogen receptors and human disease. J Clin Invest, 116, 561-70.

González-Mancha R (2008). Analysis of the ERalpha germline PvuII marker in breast cancer risk. Med Sci Monit, 14, 136-43.

González-Zuloeta Ladd AM (2008). Estrogen receptor alpha polymorphisms and postmenopausal breast cancer risk. Breast Cancer Res Treat, 107, 415-9.

Herrington DM (2002). Common Estrogen receptor polymorphism augments effects of hormone replacement therapy on E-selectin but not C-reactive protein. Circulation, 105, 1879-82.

Hill SM, Fuqua SAW, Chamness GC, Greene GL, McGuire WL (1989). Estrogen receptor expression in human breast cancer associated with an estrogen receptor gene restriction fragment length polymorphism. Cancer Res, 49, 145-8.

Hsieh YY, Wang YK, Chang CC, Lin CS (2007). Estrogen receptor $\alpha-351 \mathrm{XbaI} * \mathrm{G}$ and $-397 \mathrm{PvuII} * \mathrm{C}$-related genotypes and alleles are associated with higher susceptibilities of endometriosis and leiomyoma. Mol Hum Reprod, 13, $117-22$.

$\mathrm{Hu}$ X (2017). Association of three single nucleotide polymorphisms of ESR1 with breast cancer susceptibility: a meta-analysis. J Biomed Res, 31, 213-25.

Li G, Yang M, Li X, Deng S (2017). Comprehensive assessment of the association between estrogen receptor of alpha polymorphisms and the risk of prostate cancer: evidence from a meta-analysis. Oncotarget, 8, 102310-20.

Li LW, Xu L (2012). Menopausal status modifies breast cancer risk associated with ESR1 PvuII and XbaI polymorphisms in asian women: A HuGE review and meta-analysis. Asian Pac J Cancer Prev, 13, 5105-11.

$\mathrm{Lu} \mathrm{H}$ (2013). Estrogen receptor alpha gene polymorphisms and breast cancer risk: a case-control study with meta-analysis combined. Asian Pac J Cancer Prev, 14, 6743-9.

Nindrea RD, Aryandono T, Lazuard L (2017). Breast cancer risk from modifiable and non-modifiable risk factors among women in Southeast Asia: a meta-analysis. Asian Pac J Cancer Prev, 18, 3201-6.

Ponglikitmongkol M, Green S, Chambon P (1988). Genomic organization of the human oestrogen receptor gene. EMBO $J, 7,3385-8$.

Saggu S, Rehman H, Abbas ZK, Ansari AA (2015). Recent incidence and descriptive epidemiological survey of breast cancer in Saudi Arabia. Saudi Med J, 36, 1176-80

Saudi Cancer Registry Report (2005). Saudi Cancer Registry, Saudi Oncology Society. Available from: http://www.scr. org.sa/reports/ SCR 2005.pdf.

Shin A (2003). Estrogen receptor alpha gene polymorphisms and breast cancer risk. Breast Cancer Res Treat, 80, 127-31.

Sonestedt E (2009). The protective association of high plasma enterolactone with breast cancer is reasonably robust in women with polymorphisms in the estrogen receptor alpha and beta genes. $J$ Nutr, 139, 993-1001.

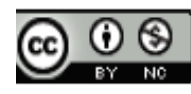

This work is licensed under a Creative Commons AttributionNon Commercial 4.0 International License. 